\title{
A rare co-occurrence of duchenne muscular dystrophy, congenital adrenal hypoplasia and glycerol kinase deficiency due to Xp21 contiguous gene deletion syndrome: case report
}

Asanka Rathnasiri , Udara Senarathne' ${ }^{2}$ Visvalingam Arunath', Thabitha Hoole ${ }^{1}$, Ishara Kumarasiri', Oshanie Muthukumarana ${ }^{1}$, Eresha Jasinge ${ }^{3}$ and Sachith Mettananda ${ }^{1,4^{*}}$

\begin{abstract}
Background: Contiguous gene deletion syndromes are rare genomic disorders caused by deletion of large segments of DNA resulting in co-occurrence of apparently unrelated multiple clinical phenotypes. We report a boy with contiguous gene deletion involving Xp21 genomic location.

Case presentation: A Sri Lankan boy with developmental delay and failure to thrive first presented at three years of age with hypovolaemia, hyperpigmentation and drowsiness. Investigations done at that time revealed hypoglycaemia, hyponatraemia, hyperkalaemia, low cortisol, low aldosterone, high ACTH and low 17-hydroxyprogesterone. He was diagnosed to have primary adrenal insufficiency.

During follow-up at five years, he was noted to have progressive difficulty in walking, waddling gait, hypotonia, calf hypertrophy and positive Gower's sign. His creatine kinase was very high, and the electromyogram showed myopathy. Genetic analysis revealed hemizygous deletion involving the final 35 exons of the dystrophin gene confirming the diagnosis of Duchenne muscular dystrophy.

Further investigations revealed pseudohypertriglyceridemia, large glycerol peak on urine organic acid analysis and hemizygous deletion of the glycerol kinase gene confirming glycerol kinase deficiency. Based on the presence of Duchenne muscular dystrophy, glycerol kinase deficiency and probable congenital adrenal hypoplasia along with genetic confirmation of deletions involving dystrophin and glycerol kinase genes, the diagnosis of Xp21 contiguous gene deletion syndrome was made.
\end{abstract}

\footnotetext{
* Correspondence: sachith.mettananda@kln.ac.lk

'Colombo North Teaching Hospital, Ragama, Sri Lanka

${ }^{4}$ Department of Paediatrics, Faculty of Medicine, University of Kelaniya,

Thalagolla Raod, Ragama, Sri Lanka

Full list of author information is available at the end of the article
}

(C) The Author(s). 2021 Open Access This article is licensed under a Creative Commons Attribution 4.0 International License, which permits use, sharing, adaptation, distribution and reproduction in any medium or format, as long as you give appropriate credit to the original author(s) and the source, provide a link to the Creative Commons licence, and indicate if changes were made. The images or other third party material in this article are included in the article's Creative Commons licence, unless indicated otherwise in a credit line to the material. If material is not included in the article's Creative Commons licence and your intended use is not permitted by statutory regulation or exceeds the permitted use, you will need to obtain permission directly from the copyright holder. To view a copy of this licence, visit http://creativecommons.org/licenses/by/4.0/ The Creative Commons Public Domain Dedication waiver (http://creativecommons.org/publicdomain/zero/1.0/) applies to the data made available in this article, unless otherwise stated in a credit line to the data. 


\begin{abstract}
Conclusions: We report a child with contiguous gene deletion syndrome who was initially diagnosed as having isolated primary adrenal insufficiency probably due to congenital adrenal hypoplasia. Later he was confirmed to have Duchenne muscular dystrophy and glycerol kinase deficiency, as well. This case report highlights the importance of pre-emptive evaluation and identification of genetic defects when patients present with seemingly unrelated diseases that could aid in accurate diagnoses of contiguous gene deletion syndromes.
\end{abstract}

Keywords: Contiguous gene deletion syndrome, Congenital adrenal hypoplasia, Duchenne muscular dystrophy, Glycerol kinase deficiency

\section{Background}

Contiguous gene deletion syndromes are rare genomic disorders caused by deletion of large segments of DNA containing several contiguous genes [1,2]. They result in the co-occurrence of apparently unrelated multiple clinical phenotypes due to defects in proteins expressed by genes which are located in close proximity to each other [2]. Here, we report a boy with three distinct clinical entities - Duchenne muscular dystrophy, congenital adrenal hypoplasia and glycerol kinase deficiency - due to contiguous gene deletion involving $\mathrm{Xp} 21$ genomic location.

\section{Case presentation}

A Sri Lankan boy was first admitted to the paediatric ward at the age of 3 years with complaints of difficulty in feeding, failure to thrive and global developmental delay. He was born to non-consanguineous parents at term with a birth weight of $2.5 \mathrm{~kg}$ and did not have significant neonatal complications. On examination, he was drowsy, had hyperpigmentation involving perioral, buccal and palmar areas and showed evidence of hypovolaemia with tachycardia and low volume pulse.

Investigations performed at that time revealed; serum sodium $120 \mathrm{mmol} / \mathrm{L}$, potassium $7.1 \mathrm{mmol} / \mathrm{L}$, glucose $30 \mathrm{mg} / \mathrm{dL}$, cortisol 4nmol/L (normal 120-626), ACTH $343 \mathrm{pg} / \mathrm{mL}$ (normal 7-41), aldosterone $0.97 \mathrm{ng} / \mathrm{dL}$ (normal 1.76-23.2), plasma renin concentration $254 \mu \mathrm{IU} / \mathrm{mL}$ (normal 2.8-32.9), plasma renin activity $21 \mathrm{ng} / \mathrm{mL} / \mathrm{hr}$ (normal 1.9-5.2), cholesterol $153 \mathrm{mg} / \mathrm{dL}$ (normal 125-170), 17hydroxyprogesterone $1.1 \mathrm{ng} / \mathrm{dL}$ (normal 3-90) and dehydroepiandrosterone sulphate $0.08 \mu \mathrm{mol} / \mathrm{L}$ (normal 0.7 5.7). Serum levels of thyroid stimulating hormone and abdominal ultrasonography were normal. Based on the biochemical features of hyponatraemia, hyperkalaemia, hypoglycaemia, low cortisol, low aldosterone, high $\mathrm{ACTH}$ in the presence of low 17-hydroxyprogesterone and dehydroepiandrosterone sulphate levels, he was diagnosed to have primary adrenal insufficiency due to a defect in the initial steps of adrenal hormone biosynthesis or congenital adrenal hypoplasia. He was commenced on oral hydrocortisone and fludrocortisone.

At the age of 5 years, he was admitted again with a history of difficulty in walking and getting up from the seated position, which was gradually worsening. Physical examination at this point revealed bilateral calf hypertrophy, waddling gait, positive Gower's sign, hypotonia of both lower limbs, muscle power of grade 4 and normal tendon reflexes suggestive of a classical proximal myopathy (Fig. 1). His creatine kinase was 12,395U/L (normal 38-174), and electromyography showed evidence of myopathy. His electrocardiography and echocardiogram were normal. Genetic mutation analysis using multiplex ligation-dependent probe amplification method revealed hemizygous deletion encompassing final 35 exons (exon 45 to 79 ) of the dystrophin gene confirming the diagnosis of Duchenne muscular dystrophy.

Due to the co-occurrence Duchenne muscular dystrophy and primary adrenal insufficiency probably due to congenital adrenal hypoplasia, $\mathrm{Xp} 21$ contiguous gene

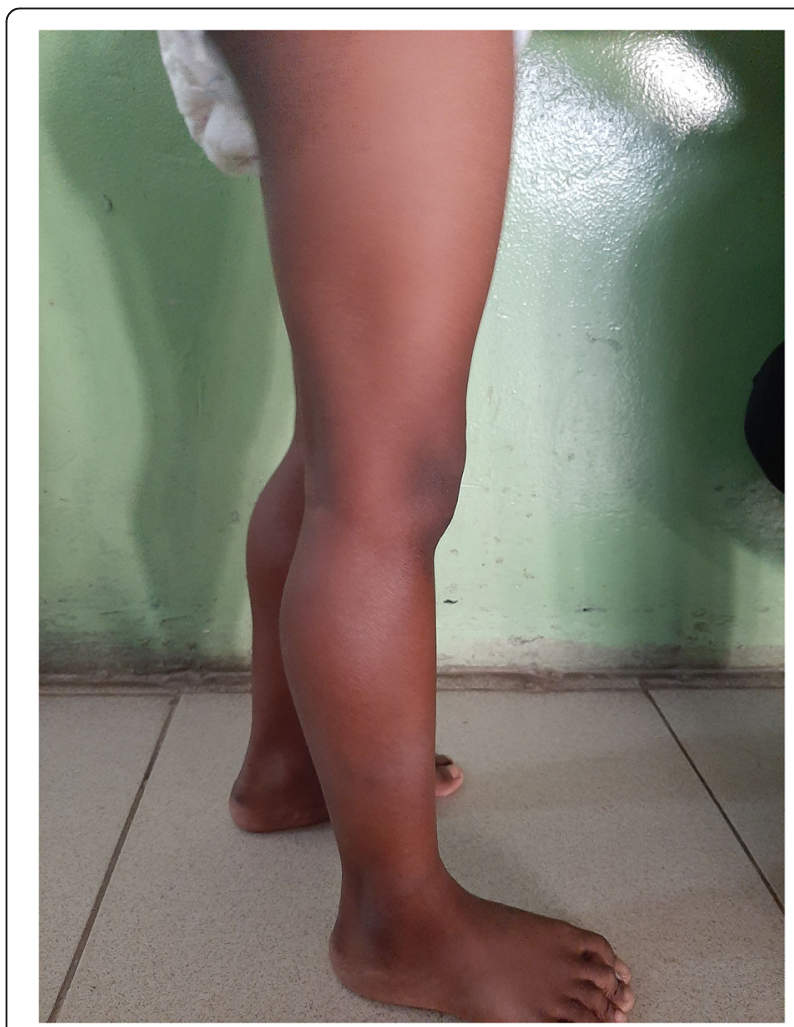

Fig. 1 Photograph of the patient showing pseudohypertrophy of the calf 
deletion syndrome was suspected. Further investigations revealed hypertriglyceridemia $(4.0 \mathrm{mmol} / \mathrm{L})$, which was associated with non-turbid serum leading to the suspicion of pseudohypertriglyceridemia due to the presence of free glycerol in serum (Fig. 2). This was confirmed by the detection of a large glycerol peak on the urinary organic acid analysis using gas chromatography-mass spectrometry (Fig. 3). Genetic mutation testing by next generation sequencing based copy number variation analysis confirmed glycerol kinase deficiency due to hemizygous deletion encompassing the entire glycerol kinase gene (exons 1 to 21). Genetic testing for congenital adrenal hypoplasia was not done due to unavailability.

Based on the presence of Duchenne muscular dystrophy, glycerol kinase deficiency and probable congenital adrenal hypoplasia along with genetic confirmation of deletions involving dystrophin and glycerol kinase genes, the diagnosis of Xp21 contiguous gene deletion syndrome was made. He was started on oral prednisolone $0.75 \mathrm{mg} / \mathrm{kg}$ daily as a treatment for Duchenne muscular dystrophy; oral hydrocortisone was discontinued, but fludrocortisone was continued. Family screening revealed intellectual disability and elevated creatine kinase level [1108 U/L (normal 26-140)] in his mother suggesting heterozygous carrier state. His only sibling, who was a 13-year old boy was clinically normal and none of the member in the extended family were affected.

\section{Discussion and conclusions}

The Xp21 contiguous gene deletion syndrome is a rare disorder characterised by co-occurrence of congenital adrenal hypoplasia, Duchenne muscular dystrophy, chronic granulomatous disease, retinitis pigmentosa, ornithine transcarbamylase deficiency, glycerol kinase deficiency

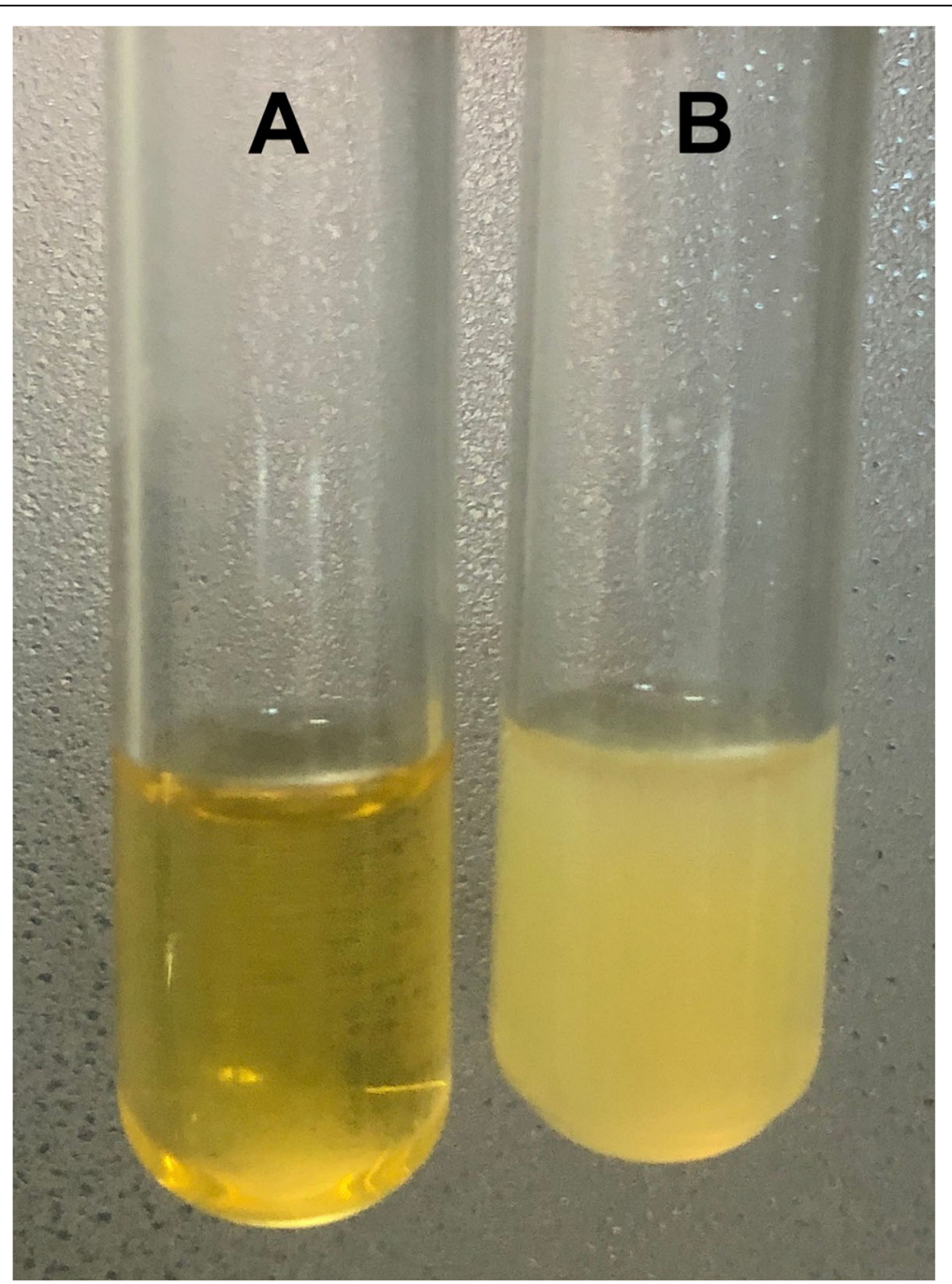

Fig. 2 Photographs of serum samples of this patient (triglyceride $4.0 \mathrm{mmol} / \mathrm{L}$ ) with clear appearance $(\mathbf{A})$ and that of a patient with true hypertriglyceridemia (triglyceride $2.1 \mathrm{mmol} / \mathrm{L}$ ) with turbid appearance (B) 


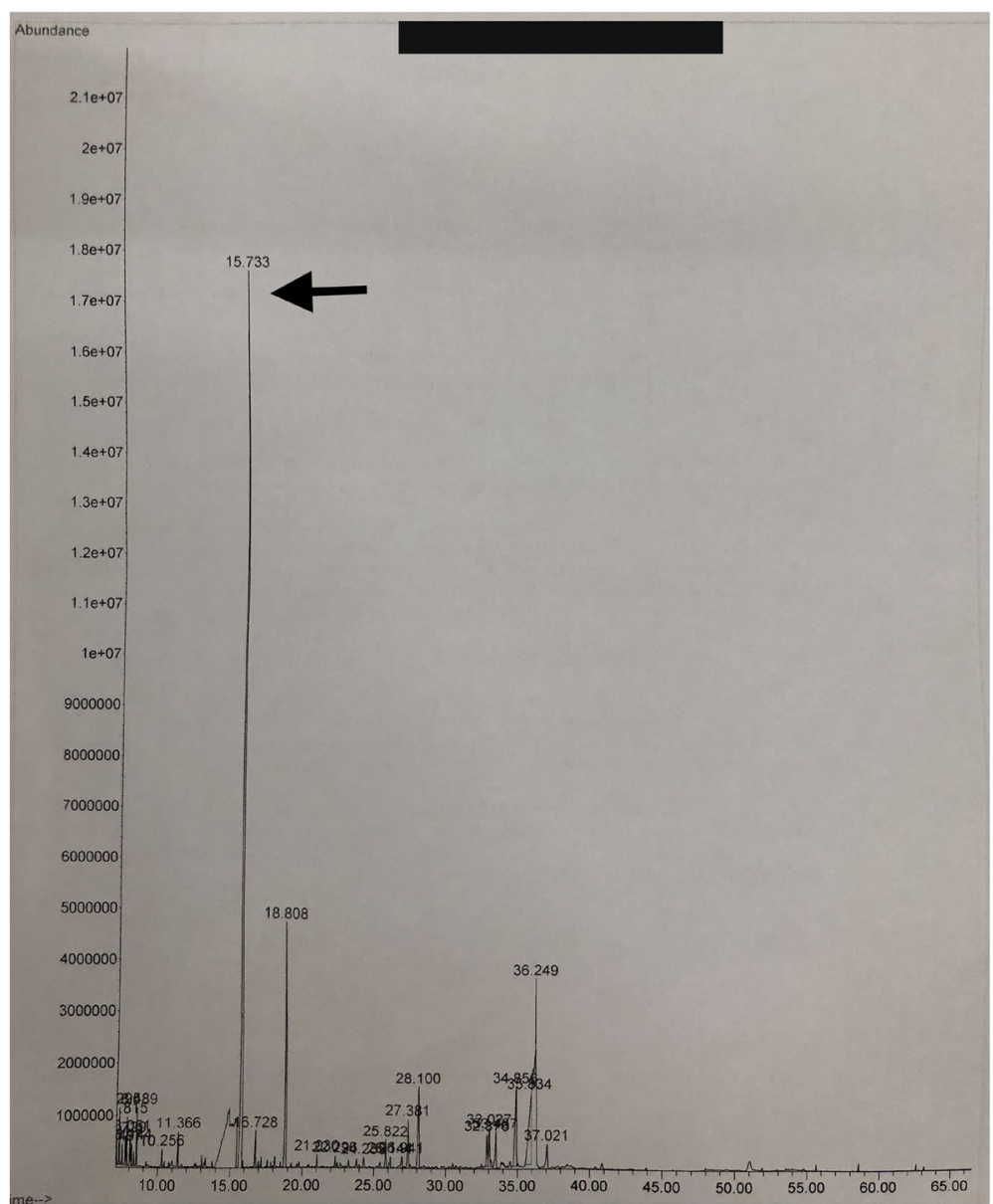

Fig. 3 Urinary organic acid analysis showing glycerol peak (arrow)

and mental retardation [3-6]. Presence of two or more features suggests the diagnosis [5]. Our patient had congenital adrenal hypoplasia, Duchenne muscular dystrophy and glycerol kinase deficiency thus confirming the diagnosis of Xp21 contiguous gene deletion syndrome.

The index patient presented initially with features of primary adrenal insufficiency. The diagnosis of congenital adrenal hypoplasia was made when he was genetically confirmed to have Duchenne muscular dystrophy and glycerol kinase deficiency at 5 years. Amongst multiple aetiologies of congenital adrenal hypoplasia, the commonest mutation affects the NROB1/DAX1 gene which is located in Xp21.2 genomic region [7]. Although mutation analysis was not performed for congenital adrenal hypoplasia in this child, the most likely genetic defect is a large deletion involving the NROB1/DAX1 gene along with dystrophin and glycerol kinase genes, which are located in close proximity to one another.

Glycerol kinase deficiency in the index patient was diagnosed following pre-emptive investigation performed due to a tentative diagnosis of Xp21 contiguous gene deletion syndrome. Glycerol kinase (IUB: 2.7.1.30) is the enzyme responsible for phosphorylation of glycerol from triglyceride breakdown for further metabolism. The absence of this enzyme activity leads to the accumulation of glycerol in circulation, causing glycerolaemia and glyceroluria $[8,9]$. The glycerolaemia is usually detected as pseudohypertriglyceridemia due to overestimation of serum triglyceride levels as a result of analytical interference by free glycerol on the assay method as observed in this patient [10]. The measurement of fasting serum triglyceride level along with visual observation of serum can be used to screen for pseudohypertriglyceridemia due to glycerolaemia. Therefore, we suggest performing this simple test in children with primary adrenal insufficiency without obvious etiological diagnoses to rule out concurrent glycerol kinase deficiency.

Hypoglycaemia is a feature in both congenital adrenal hypoplasia and glycerol kinase deficiency. In congenital adrenal hypoplasia, hypoglycaemia is due to the deficiency of counterregulatory hormone cortisol. In glycerol kinase deficiency, the conversion of glycerol to glycerol3-phosphate is impaired thus limiting substrate for gluconeogenesis. Thus, in Xp21 contiguous gene deletion, 
hypoglycaemia is a combine effect of congenital adrenal hypoplasia and glycerol kinase deficiency.

In conclusion, we report a child with contiguous gene deletion syndrome who was initially diagnosed as having isolated primary adrenal insufficiency probably due to congenital adrenal hypoplasia. This case report highlights the importance of identifying the exact genetic defects when patients present with seemingly unrelated genetic diseases which could lead to accurate diagnoses of contiguous gene deletion syndromes.

\section{Abbreviations}

DNA: Deoxyribonucleic acid

\section{Acknowledgements}

Not applicable.

\section{Authors' contributions}

$A R, V A, T H, I K, O M$ and SM conceptualised the work and participated in acquisition and interpretation of data. US and EJ did laboratory diagnostic assays for glycerol kinase deficiency. AR, US, VA, TH, IK, OM, EJ and SM wrote and revised the manuscript. All authors read and approved the final manuscript.

\section{Funding}

No funding.

\section{Availability of data and materials}

Not applicable.

\section{Declarations}

Ethics approval and consent to participate

Not applicable.

\section{Consent for publication}

Written consent to report and publish the case report, including individual images of the child (clinical photographs) was obtained from the mother of the child.

\section{Competing interests}

The authors declare that they have no competing interests.

\section{Author details}

${ }^{1}$ Colombo North Teaching Hospital, Ragama, Sri Lanka. ${ }^{2}$ Department of Biochemistry, Faculty of Medical Sciences, University of Sri Jayewardenepura, Nugegoda, Sri Lanka. ${ }^{3}$ Lady Ridgeway Children's Hospital, Colombo 08, Colombo, Sri Lanka. ${ }^{4}$ Department of Paediatrics, Faculty of Medicine, University of Kelaniya, Thalagolla Raod, Ragama, Sri Lanka.

Received: 24 December 2020 Accepted: 15 October 2021

Published online: 24 October 2021

\section{References}

1. Cole DEC, Clarke LA, Riddell DC, Samson KA, Seltzer WK, Salisbury S. Congenital adrenal hypoplasia, Duchenne muscular dystrophy, and glycerol kinase deficiency: Importance of laboratory investigations in delineating a contiguous gene deletion syndrome. Clin Chem. 1994;40(11 I):2099-103.

2. Sevim U, Fatma D, Ihsan E, Gulay C, Nevin B. A neonate with contiguous deletion syndrome in XP21. J Pediatr Endocrinol Metab. 2011;24(11-12): 1095-8.

3. Marlhens F, Chelly J, Kaplan JC, Lefrancois D, Harpey JP, Dutrillaux B. Familial deletion of Xp21.2 with glycerol kinase deficiency and congenital adrenal hypoplasia. Hum Genet. 1987;77(4):379-83.

4. Clarke A, Roberts SH, Thomas NST, Whitfield A, Williams J, Harper PS. Duchenne muscular dystrophy with adrenal insufficiency and glycerol kinase deficiency: High resolution cytogenetic analysis with molecular biochemical, and clinical studies. J Med Genet. 1986;23(6):501-8.
5. Chelly J, Marlhens F, Dutrillaux B, Van Ommen GJ, Lambert M, Haioun B, et al. Deletion proximal to DXS68 locus (L1 probe site) in a boy with Duchenne muscular dystrophy, glycerol kinase deficiency, and adrenal hypoplasia. Hum Genet. 1988;78(3):222-7.

6. C DCW, N KL, P.L.S. I. A case of congenital adrenal hypoplasia caused by the deletion of DAX-1 gene on $X$ chromosome. Hong Kong Journal of Paediatrics [Internet]. 2005;10(2):119--122+164. Available from: http://www. embase.com/search/results?subaction=viewrecord\&from=export\&id=L4054 6431.

7. Peter M, Viemann M, Partsch CJ, Sippell WG. Congenital adrenal hypoplasia: Clinical spectrum, experience with hormonal diagnosis, and report on new point mutations of the DAX-1 gene. J Clin Endocrinol Metab. 1998;83(8): 2666-74.

8. Francke U, Harper JF, Darras BT, Cowan JM, McCabe ER, Kohlschütter A, et al. Congenital adrenal hypoplasia, myopathy, and glycerol kinase deficiency: Molecular genetic evidence for deletions. Am J Hum Genet. 1987;40(3):212-27.

9. Sjarif D, Hellerud C, Amstel J, Kleijer W, Sperl W, Lacombe D, et al. Glycerol kinase deficiency: residual activity explained by reduced transcription and enzyme conformation. Eur J Hum Genet. 2004;12(6):424-32.

10. Rughani A, Blick K, Pang H, Marin M, Meyer J, Tryggestad J. Pseudohypertriglyceridemia: A Novel Case with Important Clinical Implications. Case Reports in Pediatrics. 2020;1-4.

\section{Publisher's Note}

Springer Nature remains neutral with regard to jurisdictional claims in published maps and institutional affiliations.

\section{Ready to submit your research? Choose BMC and benefit from:}

- fast, convenient online submission

- thorough peer review by experienced researchers in your field

- rapid publication on acceptance

- support for research data, including large and complex data types

- gold Open Access which fosters wider collaboration and increased citations

- maximum visibility for your research: over $100 \mathrm{M}$ website views per year

At BMC, research is always in progress.

Learn more biomedcentral.com/submissions 